\title{
Pendidikan Islam Multikultural Sebagai Modal Sosial Budaya Masyarakat Pluralis (Studi Tradisi Ngejot di Desa Lenek Kecamatan Aikmel Lombok Timur NTB)
}

\author{
Naharudin \\ Manajemen Pendidikan Islam Pascasarjana UIN Mataram \\ naharudinmuhammad@gmail.com
}

\begin{abstract}
Abstrak; Tujuan pendidikan Islam bukanlah sebatas mengisi pikiran dengan ilmu pengetahuan, tetapi meluas sebagai pembudayaan (enkulturasi), yakni pembentukan karakter dan watak masyarakat serta pembersihkan jiwa dengan akhlak yang baik dan nilai-nilai yang luhur. Hal tersebut sesuai dengan tujuan pendidikan multikultural, yaitu untuk menciptakan kehidupan yang harmonis dalam masyarakat yang serba majemuk. Sikap tersebut berawal dari kesadaran untuk saling menerima, mengakui dan menghargai orang lain dengan berbagai latar belakang yang ada, seperti etnis, ras, suku, aliran dan agama. Penanaman sikap dan nilai-nilai inklusif inilah yang menjadi akar dan pondasi dalam sistem pendidikan multikultural, terutama dalam pendidikan Islam. Tulisan ini menyajikan akulturasi tradisi budaya dan agama yang mendorong masyarakat agar memiliki sikap dan perilaku yang pluralis terhadap keberanekaragaman sehingga memandang orang lain setara dengan dirinya. Akulturasi tradisi keagamaan dan budaya lokal, seperti tradisi Ngejot di desa Lenek kecamatan Aikmel Lombok Timur merupakan bentuk tradisi melestarikan budaya leluhur dengan memberikan berbagai jenis makanan kepada sesama. Tradisi ini tetap langgeng di tengah- tengah gempuran modernisasi dan globalisasi yang pada muaranya menyebabkan pergeseran maupun pengikisan nilai dan sikap budaya masyarakat. Namun masyarakat di desa Lenek tetap menjaga dan mempertahankan tardisi yang ada khsusunya tardisi Ngejot ini. Keunikan lainnya dari tradisi ini terlihat dari bagaimana tradisi ini dikemas dalam sebuah festival. Penelitian ini menggunakan metode kualitatif dengan pendekatan studi kasus. Hasil penelitian menunjukkan bahwa, tradisi Ngejot merupakan implementasi dari nilai-nilai pendidikan Islam multikultural yang mengandung beberapa nilai, seperti silaturrahim, shadaqah, musyawarah, tasamuh, tolong menolong, saling berkasih saying, melawan hawa nafsu, menjaga perdamaian dan keamanan, dan patuh kepada pemimpin. Selain itu, Ngejot adalah tradisi yang mampu memberikan solusi kerukunan umat beragama di desa Lenek pada khususnya dan Lombok umumnya.
\end{abstract}

\section{Kata kunci: Pendidikan Islam Multikultural, Masyarakat Pluralis, Tradisi Ngejot}

\section{PENDAHULUAN}

Di tengah bangsa dan masyarakat yang multikultural-multireligius, persoalan sosialbudaya keagamaan adalah persoalan yang kompleks. Kompleksitas dilihat dari agama yang dipeluk dan faham-faham keagamaan yang diikuti, oleh Tuhan juga tidak dilihat sebagai bencana, tetapi justru diberi ruang untuk saling bekerjasama agar tercipta suatu sinergi. Kompleksitas hubungan sosial budaya umat beragama ini dirasakan oleh seluruh elemen dalam masyarakat, mulai dari pejabat, wirausaha, politisi, guru, tokoh agama, tokoh masyarakat, dan para orang tua. Menafikan keberadaan tradisi-tradisi agama di muka bumi merupakan usaha yang sia-sia karena masingmasing mempunyai hak yang sama; masing- masing mempunyai cara untuk mempertahankan tradisi dan identitasnya sendiri-sendiri dengan berbagai cara yang bisa dilakukan. Dalam menghadapi kemajemukan seperti itu tentu saja kita tidak mungkin mengambil sikap anti pluralisme. Kita harus belajar toleran tehadap kemajemukan. Kita dituntut untuk hidup di atas dasar dan semangat pluralisme agama.

Salah satu upaya yang dapat dilakukan untuk memperjuangkan masyarakat yang pluralis adalah melalui pendidikan yang multikultural. Pengertian pendidikan multikultural menunjukkan adanya keragaman dalam pengertian istilah tersebut.

Menurut Amin Abdullah, cara yang paling tepat untuk mempertahankan tradisi dan identitas keagamaan di atas adalah melalui 
jalur pendidikan. Hal ini disebabkan karena pendidikan adalah alat yang paling efektif untuk meneruskan, melanggengkan, mengawetkan, dan mengonservasi tradisi dari satu generasi ke generasi selanjutnya, dari abad yang satu ke abad yang lain.

Pendidikan sebagai sebuah proses pengembangan sumber daya manusia agar memperoleh kemampuan sosial dan perkembangan individu yang optimal memberikan relasi yang kuat antara individu dengan masyarakat dan lingkungan budaya sekitarnya. Lebih dari itu pendidikan merupakan proses "memanusiakan manusia" dimana manusia diharapkan mampu memahami dirinya, orang lain, alam dan lingkungan budayanya. Atas dasar inilah pendidikan tidak terlepas dari budaya yang melingkupinya sebagai konsekwensi dari tujuan pendidikan yaitu mengasah rasa, karsa dan karya. Hal ini pulah yang menjadi tujuan pendidikan dalam Islam. Pencapaian tujuan pendidikan tersebut menuai tantangan sepanjang masa karena salah satunya adalah perbedaan budaya.

Oleh karena itulah, kita dihadapkan pada kebutuhan terhadap pendidikan yang mampu mengakomodasi dan memberikan pembelajaran yang mampu bersikap toleran terhadap budaya lain sangatlah penting. Pendidikan yang memiliki basis multikultural akan menjadi salah satu solusi dalam pengembangan sumberdaya manusia yang mempunyai karakter yang kuat dan toleran terhadap budaya lain. Dengan kata lain, penekanan utama multikulturalisme adalah pada kesetaraan budaya.

Pertautan antara Pendidikan dan Multikultural merupakan solusi atas realitas budaya yang beragam sebagai sebuah proses pengembangan seluruh potensi yang menghargai pluralitas dan heterogenitas sebagai konsekwensi keragaman budaya, etnis, suku dan aliran atau agama. Pluralitas budaya, sebagaimana terdapat di Indonesia,menempatkan pendidikan Multikultural menjadi sangat urgen. Keberagaman budaya di Indonesia merupakan kenyataan historis dan sosial yang tidak dapat disangkal oleh siapapun. Keunikan budaya yang beragam tersebut memberikan implikasi pola pikir, tingkah laku dan karakter pribadi masingmasing sebagai sebuah tradisi yang hidup dalam masyarakat dan daerah. Tradisi yang terbentuk akan berlainan dari satu suku/ daerah dengan suku/daerah yang lain. Pergumulan antar budaya memberikan peluang konflik manakala tidak terjadi saling memahami dan menghormati satu sama lain. Proses untuk meminimalisir konflik inilah memerlukan upaya pendidikan yang berwawasan Multikultural dalam rangka pemberdayaan masyarakat yang majemuk dan heterogen agar saling memahami dan menghormati serta membentuk karakter yang terbuka terhadap perbedaan.

Begitu pula dengan mencermati berbagai berita di televisi dan surat kabar, kondisi karakter bangsa Indonesia telah mengalami krisis yang perlu mendapatkan perhatian yang serius. Krisis karakter kemanusiaan dapat dicermati dari gejala-gejala seperti korupsi yang merajalela dari tingkatan eksekutif, legeslatif, dan yudikatif yang sulit untuk diberantas, lemahnya disiplin, mental menerabas, melemahnya nasonalisme atai keindonesiaan, menurunnya kemampuan menerima dan menghargai perbedaan, mudahnya masyarakat terpancing konflik yang dipicu hal-hal sepele maupun dipicu karena perbedaan agama, etnis, maupun budaya. Di sinilah pendidikan multikultural hadir sebagai solusi terhadap semua problema tersebut.

Pendidikan Multikultural juga senada dengan tujuan agama Islam yang berbunyi "Tujuan umum syari'ah Islam adalah mewujudkan kepentingan umum melalui perlindungan dan jaminan kebutuhankebutuhan dasar (al-daruriyyah) serta pemenuhan kepentingan (al-hajiyyat) dan penghiasan (tahsiniyyah) mereka." Dari konsep inilah kemudian tercipta sebuah konsep aldaruriyyah al-khamsah (lima dasar kebutuhan manusia), yang meliputi jiwa (al-nafs), akal (al$a q l$ ), kehormatan (al-irdh), harta benda (almal), dan agama (al-din). Dengan kata lain, konsep dasar inilah yang melahirkan istilah pendidikan Islam multikultural.

Pendidikan Islam multikultural juga dapat dipahami sebagai proses pendidikan yang 
berprinsip pada demokrasi, kesetaraan dan keadilan; berorientasi kepada kemanusiaan, kebersamaan, dan kedamaian; serta mengembangkan sikap mengakui, menerima dan menghargai keragaman berdasarkan al-Qur'an dan hadis. Tujuan pendidikan Islam bukan sebatas mengisi pikiran siswa dengan ilmu pengetahuan dan materi pelajaran akan tetapi membersihkan jiwanya yang harus diisi dengan akhlak dan nilai-nilai yang baik dan dikondisikan supaya biasa menjalani hidup dengan baik. Pendidikan Islam multikultural juga merupakan cermin keseimbangan antara pemahaman persamaan dan perbedaan budaya mendorong individu untuk mempertahankan dan memperluas wawasan budaya dan kebudayaan mereka sendiri.

Adapun salah satu kearifan lokal yang dapat dijadikan pedoman dan dasar dalam rangka pendidikan multikultural sekaligus tujuan pendidikan Islam adalah nilai-nilai kearifan lokal masyarakat sasak di desa Lenek Kecamatan Aik Mel Kabupaten Lombok Timur Nusa Tenggara Barat. Warga Tenganan Pageringsingan memiliki tradisi tersendiri dalam mendidik anak-anak mereka sebagai generasi muda sebagai pemegang estapet roda kehidupan desa dan tradisi mereka terus diputar. Nilai kearifan lokal yang bisa dieksplor salah satunya adalah tradisi Ngejot. Hal ini dikarenakan masyarakat Sasak Lenek dikenal sebagai masyarakat yang kaya akan warisan falsafah kehidupan serta sangat menjunjung tinggi nilai-nilai kemanusiaan.

Berbagai penelitian terkait Tradisi Ngejot masyarakat Sasak sedikit sekali. Salah satu diantaranya adalah penelitian tentang kearifan lokal tradisi Ngejot masyarakat Sasak dan relevansinya dengan pendidikan karakter. Dalam penelitian ini (I Ketut Margi dkk, 2016) ditemukan bahwa kearifan lokal tradisi Ngejot masyarakat Sasak Lenek memiliki kandungan nilai-nilai kearifan lokal yang digunakan dan diterapkan oleh masyarakat secara turun-temurun. Hasil penelitian menunjukkan bahwa (1) latar belakang adanya tradisi ngejot di Desa Lenek, mempererat silaturhomi, menjaga solidaritas antarsesama, (2) tradisi ngejot dipertahankan oleh masyarakat Desa Lenek, karena adanya faktor kepercayaan, faktor budaya, meningkatkan solidaritas sosial, faktor pendidikan, pemenuhan kebutuhan akan keselamatan, (3) nilai-nilai karakter yang ada dalam tradisi ngejot (religius, cintai damai, disiplin, tanggung jawab, perduli lingkungan), (4) pemamfaatan tradisi ngejot sebagai media pendidikan karakter melalui pembelajaran sejarah di sekolah-sekolah, agar nantinya budaya tersebut dapat memperkaya materi pembelajaran sejarah dan karakter siswa.

Dalam tradisi Ngejot tercermin nilai-nilai kearifan lokal pada empat aspek. Pertama, aspek religius masyarakat Sasak Lenek sangat kental dengan ajaran Islam. Hal ini tampakpada aktivitas masyarakat, baik dalam hubungan manusia dengan pencipta, hubungan manusia dengan manusia, dan hubungan manusia dengan alam. Kedua, aspek norma masyarakat Sasak Lenek memiliki kedisiplinan pada aturan, adil pada penerapan hukum, dan bermawas diri. Ketiga, pada aspek sosial masyarakat Sasak Lenek memiliki nilai-nilai luhur, kasih sayang, saling peduli, saling menghormati, toleransi pada keberagaman, dan saling menghargai. Keempat, nilai-nilai kearifan lokal pada kabanti masyarakat Sasak Lenek relevan dengan pilar-pilar pendidikan karakter sehingga dapat diimplementasikan oleh guru pada pembelajaran karakter sebagai modal kehidupan dalam masyarakat yang pluralis.

Peneliti juga menilai bahwasanya tradisi ngejot ini juga bisa menjadi representasi dari dakwah bil hal untuk menyampaikan pesan kerukunan beragama, dan bukan hanya tradisi ngejot, banyak tradisi di Lombok seperti tradisi Sabuk Belo, Tandang Mendet, Bebelus Batu, Begasingan, Peresean, Lomba Memaos, Gendang Belek, Tongkek, Bau Nyale, Upacare Rebo Bontong, Slober, dan lainnya menjadi warisan budaya yang kaya akan nilainilai pendidikan moral dan kemanusiaan. Dan terbukti, tradisi-tradisi tersebut khususnya tradisi Ngejot dipertahankan hingga hari ini. Kajian ini diharapakan bisa menjadi salah satu khazanah keilmuan dan referensi dalam disiplin ilmu Islamic Studies yang berwawasan kebudayaan dan kearifan lokal 
yang sudah dimiliki masyarakat Nusantara sebelum datangnya Islam. Oleh karena itu, peneliti tertarik untuk melakukan penelitian dengan judul "Pendidikan Islam Multikultural Sebagai Modal Sosial Budaya Masyarakat Pluralis: Studi Tradisi Ngejot di Desa Lenek Kecamatan Aik Mel Lombok Timur NTB"

\section{METODE PENELITIAN}

Penelitian ini merupakan bentuk penelitian yang menggunakan analisis isi (content analysis), sehingga pelaksanaannya mengacu pada prosedur analisis isi. Oleh karena itu peneliti mengembangkan dua langkah (prosedur) pertama, pengadaan data yaitu (a) penentuan unit analisis melalui pembacaan secara cermat dan berulang, (b) perekaman dan pencatatan data menjadi masalah pokok karena analisis konten berupa data simbolik yang tidak berstruktur. Kedua,validasi data yakni menggunakan pola validasi semantik yakni mengukur tingkat kesensitifan makna simbolik yang berkaitan dengan konteks. Ketiga, proses inferensi dan analisis sebagai salah satu prosedur analisis konten. Inferensi dimaksudkan untuk menarik simpulan yang bersifat abstrak. Selanjutnya melakukan penyajian dan pembahasan data.

\section{LANDASAN TEORI}

\section{Pendidikan Islam}

Pendidikan sebagai suatu sistem terdiri dari berbagai komponen yang antara satu dan lainnya saling berkaitan. Komponen pendidikan dalam standar pendidikan nasional meliputi visi, misi, tujuan, kurikulum, proses belajar mengajar, pendidik, peserta didik, manajemen, sarana prasarana, pembiayaan, sistem komunikasi, evaluasi, lingkungan, dan jaringan komunikasi. Komponen-komponen tersebut yang secara kodrati terbagi menjadi beberapa ruang, yaitu agama, sosial, budaya, politik, sosiologi, antropogi, ekonomi, dan lain-lain. Secara agama pendidikan itu tidak cukup dimanifestasikan dalam upacaraupacara seremonial belaka, tetapi dalam seluk beluk proses beragama yang berangkat dari berbagai macam disiplin keilmuan. Dari konsep sederhana inilah kemudian lahir istilah pendidikan Islam.
Pendidikan Islam secara etimologi diwakili oleh istilah ta'lim dan tarbiyah yang berasal dari kata dasar 'allama dan rabba sebagaimana dalam al Quran. Sesuai dengan pendapat Maksum Mukhtar dengan mengutip Majid Irsan al-Kailani dalam Tatawwur Mafhum al-Nazariyyah al-Tarbawiyyah, bahwa untuk mendapat suatu makna dari istilah, maka kita melakukan pembahasan terhadap istilah-istilah yang berkaitan dengan derivisasi makna aslinya.

Sedangkan menurut terminologi, pendidikan Islam adalah usaha mengubah tingkah laku individu dalam kehidupan kepribadian dan kemasyarakatan yang dilandasi nilai-nilai keislaman. Dengan kata lain pendidikan Islam itu lebih menekankan pada proses dalam usaha pengamalan nilainilai keislaman itu sendiri.

Secara sederhana pendidikan Islam dapat diartikan sebagai pendidikan yang didasarkan pada nilai-nilai ajaran Islam sebagaimana yang tercantum dalam al quran dan hadist serta pemikiran para ulama dan dalam praktik sejarah umat Islam dan berorientasi kepada masyarakat. Dijadikannya masyarakat sebagai dasar, menunjukkan karakter ajaran Islam yang fleksibel dan berlaku di semua tempat dan waktu, sehingga terjalin hubungan antara teks dan konteks. Dengan demikian segala komponen dalam pendidikan mulai dari visi, misi, tujuan, kurikulum, guru, metode, pola hubungan guru murid, evaluasi, sarana prasarana, lingkungan, dan evaluasi pendidikan hendaknya didasarkan pada nilainilai islam dengan tujuan pembentukan akhlakul karimah sebagai tiang pendidikan Islam, menurut ukuran-ukuran Islam, dan etika profetik, yaitu etika yang dikembangkan atas dasar nilai-nilai ilahiah dalam pengembangan ilmu agar mereka berkepribadian dan hidup sesuai ajaran dan hukum-hukum Islam, serta melestarikan budaya-budaya masyarakat sepanjang sejalan dengan nilai-nilai ajaran Islam.

Dari uraian di atas, dapat disimpulkan bahwa ajaran Islam sebagaimana dijumpai dalam al quran dan penjabarannya dalam hadis telah meletakkan dasar-dasar yang khas tentang konsep pendidikan dalam Islam yang 
diimplementasikan dalam bentuk kelembagaan dan komponen aktivitas pendidikan lainnya, yang kesemuanya hal tersebut didasarkan dan disemangati oleh nilai-nilai keislaman.

Abu Ahmadi mengatakan bahwa tahaptahap tujuan pendidikan Islam meliputi: a) tujuan tertinggi/terakhir, b) tujuan umum, c) tujuan khusus, dan d) tujuan sementara. Tujuan tertinggi bersifat mutlak. Dalam tujuan pendidikan Islam, tujuan tertinggi ini pada akhirnya sesuai dengan tujuan akhir hidup manusia dan peranannya sebagai makhluk ciptaan Allah SWT., seperti menjadi hamba Allah, mengantarkan peserta didik menjadi khalifah $f i$ al-ardh, dan untuk memperoleh kesejahteraan, kebahagiaan hidup di dunia akhirat. Tujuan pendidikan Islam lebih mengutamakan pendekatan filosofik yang bersifat empirik dan realistic, yaitu berfungsi sebagai arah yang taraf pencapaiannya dapat diukur menyangkut perubahan sikap, prilaku,dan kepribadian peserta didik, seperti mampu merealisasikan diri, menampilkan diri menjadi pribadi muslim yang menebarkan ajaran Islam Rahmatan Lil Alamin.

2. Pendidikan Multikultural

a. Pluralisme

Sebelum berbicara terlalu jauh mengenai multikulturalisme, perlu diketahui sebuah istilah yang dekat dengan multikultural itu sendiri, yaitu pluralisme. Prulalisme merupakan teori yang mengatakan bahwa realitas terdiri dari banyak substansi. Menurut asal katanya, pluralisme berasal dari bahasa Inggris, yaitu pluralism. Apabila merujuk dari wikipedia bahasa Inggris maka definisi pluralisme adalah: "In the social sciences, pluralism is a framework of interaction in which groups show sufficient respect and tolerance of each other, that they fruitfully coexist and interact without conflict or assimilation (Suatu kerangka interaksi yang mana setiap kelompok menampilkan rasa hormat dan toleran satu sama lain, berinteraksi tanpa konflik atau asimilasi/pembiasaan)".

Jadi, pluralisme adalah sebuah paham yang menekankan aspek- aspek positif dalam sebuah realitas keberagaman, toleransi dan mengakui keberadaan golongan (agama) lain yang berbeda sebagai upaya preventif dalam menanggulangi konflik antar agama. Maka, pluralisme seharusnya dipahami dan diterima secara positif, bukan digugat secara negatif, apalagi sampai diklaim sebagai paham yang merusak akidah, khususnya bagi umat Islam.

Pluralitas dalam masyarakat mempunyai tanggapan yang berbeda dari pendangan masyarakat secara umum, ada yang mengatakan bahwa aspek pluralisme merupakan sumber konflik sosial ditengah masyarakat, sebagaimana disampaikan Abd. Rahman Assegaf mengutip pernyataan Tobroni dan Samsul Arifin, sebagai berikut: "Pluraliseme sering dipahami sebagai salah satu faktor pemicu konflik sosial" Abd. Rahman Assegaf menambahkan pendapat dari H.M Sanusi, "Padahal umumnya konflik atau kerusuhan yang terjadi ditengah masyarakat disebabkan faktor dominan ketimpangan sosial," ketimbang agama atau etnis. Assegaf mengutip lagi pendapat Baharuddin, Umat beragama sendiri tidak rusuh dengan sesama mereka, hanya saja umat beragama dijadikan alat untuk mempercepat kerusuhan.

Seringnya munculnya konflik horizontal di tengah masyarakat pluralis religius, yang mengarah kepada pertentangan SARA, membuat isu tentang peranan agama bagi kelangsungan hidup yang tenteram dan toleran terus menarik untuk diperbincangkan. Sebagai negara yang menempatkan agama sebagai falsafah moral kehidupan berbangsa, adalah penting untuk mengkaji bagaimana peranan pendidikan agama terhadap upaya pemerintah dalam mereduksi konflik yang sering muncul di Tanah Air. Apa yang salah dengan pendidikan agama di Tanah Air sehingga seolah-olah agama sebagai landasan moral bangsa kurang mempunyai peranan signifikan dalam mencegah terjadinya konflik.

Konflik dan kekerasan sosial yang sering terjadi antara kelompok masyarakat merupakan bagian dari sikap toleransi yang tidak bisa dikelola dengan baik. Adapun faktor-faktor yang memicu terjadinya pelanggaran kebebasan beragama tersebut 
diantaranya: doktrin agama yang fanatiq dan terlalu subjektif dalam memberikan penilaian terhadap agamanya, dipicu oleh benturan akibat perbedaan suku, ras dan kebudayaan serta timbulnya gesekan antara kaum mayoritas dan minoritas yang tidak terhindarkan.

b. Pengertian Multikulturalisme

Akar kata multikulturalisme adalah kebudayaan. Secara etimologis, multikulturalisme dibentuk dari kata multi (banyak), kultur (budaya), dan isme (aliran/paham). Secara hakiki, dalam kata itu terkandung pengakuan akan martabat manusia yang hidup dalam komunitasnya dengan kebudayaannya masing-masing yang unik. Dengan demikian, setiap individu merasa dihargai sekaligus merasa bertanggung jawab untuk hidup bersama komunitasnya. Pengingkaran suatu masyarakat terhadap kebutuhan untuk diakui (politics of recognition) merupakan akar dari segala ketimpangan dalam berbagai bidang kehidupan.

Pengertian kebudayaan di antara para ahli harus dipertaruhkan atau dipertentangkan antara satu konsep yang dipunyai oleh seorang ahli dengan konsep yang dipunyai ahli lainnya. Karena multikulturalisme itu adalah sebuah ideology dan sebuah alat atau wahana untuk meningkatkan derajat manusia dan kemanusiaannya, maka konsep kebudayaan harus dilihat dalam perspektif fungsinya bagi kehidupan manusia. Pendidikan dianggap wahana paling tepat untuk membangun kesadaran multikulturalisme. Sebab, dalam tataran ideal, pendidikan seharusnya bias berperan sebagai "juru bicara" bagi terciptanya fundamen kehidupan multikultural yang terbebas dari kooptasi negara. Harus diakui juga bahwa multikulturalisme kebangsaan Indonesia belum sepenuhnya dipahami oleh segenap warga masyarakat sesuatu yang given, takdir Tuhan, dan bukan faktor bentukan manusia.

Masyarakat majemuk (plural society) belum tentu dapat dinyatakan sebagai masyarakat multikultural (multicultural society), karena bisa saja di dalamnya terdapat hubungan antarkekuatan masyarakat varian budaya yang tidak simetris yang selalu hadir dalam bentuk dominasi, hegemoni dan kontestasi. Konsep masyarakat multikultural sebenarnya relatif baru. Sekitar 1970-an, gerakan multikultural muncul pertama kali di Kanada. Kemudian diikuti Australia, Amerika Serikat, Inggris, Jerman dan lain-lainnya.

Dalam konteks perspektif kebudayaan tersebut, maka multikulturalisme adalah ideologi yang dapat menjadi alat atau wahana untuk meningkatkan derajat manusia dan kemanusiannya. Multikulturalisme mengakui dan mengagungkan perbedaan dalam kesederajatan baik secara individual maupun secara kebudayaan. Berbagai konsep yang relevan dengan multikulturalisme antara lain adalah demokrasi, keadilan dan hukum, nilainilai budaya dan etos, kebersamaan dalam perbedaan yang sederajat, sukubangsa, kesukubangsaan, kebudayaan sukubangsa, keyakinan keagamaan, ungkapan-ungkapan budaya, domain privat dan publik, hak asasi manusia, hak budaya komunitas, dan konsepkonsep lainnya yang relevan.

3. Nilai-Nilai Pendidikan Islam

\section{Multikultural}

Sebagai sebuah ideologi, multikulturalisme harus diperjuangkan, karena dibutuhkan sebagai landasan bagi tegaknya demokrasi, hak asasi manusia dan kesejahteraan hidup masyarakatnya. Salah satu upaya yang dapat dilakukan untuk memperjuangkan multikulturalisme adalah melalui pendidikan yang multikultural. Pengertian pendidikan multikultural menunjukkan adanya keragaman dalam pengertian istilah tersebut.

Di sisi lain pendidikan adalah transfer of knowledge atau memindah ilmu pengetahuan. Sedangkan Multikultural secara etimologis multi berarti banyak, beragam dan aneka sedangkan kultural berasal dari kata culture mempunyai makna budaya, tradisi, kesopanan atau pemeliharaan.

Dalam konteks deskriptif ini, maka kurikulum Pendidikan Islam Multikultural mestilah mencakup subjek-subjek seperti: toleransi; tema-tema tentang perbedaan ethnokultural dan agama: bahaya diskriminasi: penyelesaian konflik dan mediasi: HAM; demokratis dan pluralitas; kemanusiaan 
universal dan subjek-subjek lain yang relevan. Pendidikan Islam multikultural merupakan cermin keseimbangan antara pemahaman persamaan dan perbedaan budaya mendorong individu untuk mempertahankan dan memperluas wawasan budaya dan kebudayaan mereka sendiri. Abdullah Aly (2011) mengungkapkan setidaknya ada tiga point yang menjadi nilai-nilai pendidikan Islam Multikultural yang dapat disimpulkan, yaitu :

Ketiga karakteristik pendidikan multikultural yang dimaksud adalah :

(1) pendidikan Islam multikultural berprinsip pada demokrasi, kesetaraan dan keadilan; (2) pendidikan Islam multikultural berorientasi pada kemanusiaan, kebersamaan, dan keadamaian; (3) pendidikan Islam multikultural mengembangkan sikap mengakui, menerima, dan menghargai keragaman budaya.

Dengan memperhatikan uraian-uraian tentang karakteristik pendidikan multikultural di atas jelaslah bahwa ada kesesuaian antara nilai- nilai multikultural dalam perspektif Barat dengan nilai-nilai multikultural dalam perspektif Islam. Meskipun demikian, sember kebenaran dari nilai-nilai multikultural tersebut berbeda. Jika nilai-nilai multikultural dalam perspektif Barat bersumber dari filsafat dan bertumpu pada hak- hak asasi manusia, maka nilai-nilai multikultural dalam perspektif Islam bersumber dari wahyu.

Gambar Karakteristik pendidikan multikultural

\begin{tabular}{|l|l|l|}
\hline \multicolumn{1}{|c|}{ Karakteristik } & \multicolumn{1}{|c|}{$\begin{array}{c}\text { Nilai multicultural } \\
\text { perspektif Barat }\end{array}$} & \multicolumn{1}{|c|}{$\begin{array}{c}\text { Nilai multikultural } \\
\text { perspektif Islam }\end{array}$} \\
\hline $\begin{array}{l}\text { Berprinsip pada demokrasi, } \\
\text { kesetaraan dan keadilan }\end{array}$ & $\begin{array}{l}\text { Demokrasi, kesetaraan } \\
\text { dan keadilan }\end{array}$ & $\begin{array}{l}\text { Al-Musyawarah, al-musawah } \\
\text { dan al-'adl }\end{array}$ \\
\hline $\begin{array}{l}\text { Berorientasi pada } \\
\text { kemanusiaan, kebersamaan } \\
\text { dan kedamaian }\end{array}$ & $\begin{array}{l}\text { Kemanusiaan, } \\
\text { kebersamaan, dan } \\
\text { kedamaian }\end{array}$ & $\begin{array}{l}\text { Hablum min an-nas, al- } \\
\text { ta'aruf, al-ta'awun dan al- } \\
\text { salam }\end{array}$ \\
\hline $\begin{array}{l}\text { Mengembangkan sikap } \\
\text { mengakui, menerima dan } \\
\text { menghargai keragaman }\end{array}$ & $\begin{array}{l}\text { Toleransi,empati, } \\
\text { simpati, dan solidaritas } \\
\text { sosial }\end{array}$ & $\begin{array}{l}\text { Al-ta'addudivat, al-tanawwu', } \\
\text { al-tasamuh, al-rahmah, al- } \\
\text { 'afw dan al-ihsan }\end{array}$ \\
\hline
\end{tabular}

Landasan pendidikan Islam multikultural dapat digolongkan sebagai berikut: pertama, landasan pendidikan multikultural yang berprinsip pada demokrasi, kesetaraan dan keadilan ditemukan keberadaannya dalam alQur'an Q.S al-Syura: 38,
Artinya: "Dan (bagi) orang-orang yang menerima (mematuhi) seruan

Tuhannya dan mendirikan salat, sedang urusan mereka (diputuskan) dengan musyawarah antara mereka; dan mereka menafkahkan sebagian dari rezki yang Kami berikan kepada mereka."

Selanjutnya dalam Q.S al-Hadid: 25

Artinya: "Sesungguhnya Kami telah mengutus Rasul-rasul Kami dengan membawa bukti-bukti yang nyata dan telah Kami turunkan bersama mereka Al kitab dan neraca (keadilan) supaya manusia dapat melaksanakan keadilan. Dan Kami ciptakan besi yang padanya terdapat kekuatan yang hebat dan berbagai manfaat bagi manusia, (supaya mereka mempergunakan besi itu) dan supaya Allah mengetahui siapa yang menolong (agama)-Nya dan rasul-rasul-Nya Padahal Allah tidak dilihatnya. Sesungguhnya Allah Maha kuat lagi Maha Perkasa”.

Dan padaQ.S al-A'raf: 181

Artinya: "Dan di antara orang-orang yang Kami ciptakan ada umat yang memberi petunjuk dengan hak, dan dengan yang hak itu (pula) mereka menjalankan keadilan".

Doktrin Islam tentang prinsip demokrasi (almusyawarah), kesetaraan (al-musawah), dan keadilan (al-'adl) di atas telah dipraktikkan oleh Rasulullah Saw untuk mengelola keragaman kelompok dalam masyarakat Madinah. Peristiwa tersebut sangat populer dengan sebutan Piagam Madinah. Piagam ini menetapkan seluruh pendidikan Madinah memeroleh status yang sama atau persamaan dalam kehidupan.

\section{HASIL DAN PEMBAHASAN}

\section{Sejarah Ngejot}

Provinsi Nusa Tenggara Barat merupakan provinsi yang terletak di sebelah timur Pulau Bali. Provinsi ini terdiri dari dua Pulau besar, yakni Pulau Lombok dan Pulau Sumbawa. Adat istiadat di Provinsi Nusa Tenggara Barat sangat beragam dengan kekhasan tersendiri, seperti rumah adat, kampung adat, upacara adat kelahiran, pernikahan, kehamilan, dan kematian. Selain itu, ada pula tradisi lisan dan tradisi tulis dari setiap masyarakat.

Lombok merupakan salah satu Pulau yang terdapat di Provinsi Nusa Tenggara Barat yang memiliki aneka ragam tradisi seperti upacara adat, agama, keindahan alam dan pantainya. Pulau Lombok juga tidak bisa 
dilepaskan dari kepercayaan dan tradisitradisi yang dianggap memiliki nilai-nilai religi, kebersamaan saling menghormati, keramah-tamahan penduduknya, yang memiliki keunikan dan kekhasan yang tidak terlepas dari kehidupan masyarakat yang berciri sosial religious.

Berdasarkan pendapat di atas, tradisi_tradisi tersebut tersebar di berbagai desa di Lombok. salah satu desa dengan keragaman budaya dan tradisi, yaitu Desa Lenek yang terletak di Kecamatan Aikmel, Lombok Timur, Nusa Tenggara Barat. Tradisi-tradisi yang dimiliki antara lain tradisi Mandi Kawin, Begawe Beleq, Mangan Kelor (Megibung) Memedak (Akikah), Begetes (7 bulanan orang hamil) serta dan ngejot. Berbagai macam tradisi tersebut oleh masyarakat mampu dipertahankan meskipun di tengah-tengah masyarakat yang sebagian besar telah terkena pengaruh moderniasi. Tradisi ngejot yang ada di Desa Lenek berbeda dengan tradisi ngejot yang ada di di Bali. Tradisi ini dilaksanakan oleh umat Islam, yaitu sehari sebelum hari raya Idul Fitri.

Dari sekian banyak tradisi di Desa Lenek, tradisi ngejot menarik untuk dikaji karena tradisi ini mempunyai keunikan- keunikan yang di dalamnya mengandung nilai-nilai dan makna filosofi. Tradisi ngejot dilakukan pada hari-hari besar Islam khusunya pada hari raya Idul Fitri. Keunikan lainnya dari tradisi ini terlihat dari bagaimana tradisi ini dikemas dalam sebuah festival. Tradisi ini tetap langgeng di tengah- tengah gempuran modernisasi dan globalisasi yang pada muaranya menyebabkan pergeseran maupun pengikisan nilai dan sikap budaya masyarakat. Tidak dipungkiri tradisi mempunyai stereotife yang kolot dan sudah banyak ditinggalkan oleh para pendukungnya. Namun masyarakat di Desa Lenek tetap menjaga dan mempertahankan tardisi yang ada khsusunya tardisi ngejot ini.

Mengenai istilah ngejot ini berasal dari harafiah yang berarti "mengantarkan/membesuk/ziarah keluarga atau sering diartikan sebagai kegiatan mengantarkan makanan sesaji (dulang) dalam bentuk makanan kepada orang tua atau kelaurga yang dituakan sebagai simbol ucapan terima kasih, rasa bakti hormat sekaligus sebagai ucapan permintaan maaf sang anak dan keluarganya. Karena setiap tradisi ini dijalankan oleh seluruh masyarakat yang ada di desa Lenek. Ngejot dimaknakan secara harfiah adalah tradisi bejango atau membesuk atau ziarah ke rumah keluarga dan pemimpin seraya membawa dulang.

Kata Ngejot sendiri merupakan istilah dalam bahasa Bali yang memiliki arti "memberi." Jenis pemberiannya bisa berupa makanan, jajanan, atau buah-buahan. Secara khusus, Tradisi Ngejot di Bali terbagi ke dalam Ngejot ketika hari raya dan Ngejot ketika seseorang memiliki hajatan atau suatu acara adat atau agama tertentu. Salah satu saat pelaksanaannya adalah menjelang Hari Raya Idul Fitri. Adapun makna dari Ngejot adalah suatu tradisi berbagi makanan dan minuman masyarakat (dalam konteks ini adalah masyarakat di beberapa daerah di Bali) kepada tetangga dan kerabatnya. Makanan atau minuman yang dibagikan saat Ngejot dinamakan jotan.

Setelah datangnya umat Islam sejak abad ke-14, tradisi ngejot ini tetap dilakukan secara kontinu. Dalam ajaran agama Islam, memberi makanan adalah salah satu bentuk shadaqah, sedangkan saling mendatangi atau mengunjungi adalah silaturrahim. Jadi dapat dinilai bahwa tradisi ini tidak bertantangan dengan ajaran Islam. Oleh karena itu, tradisi ini tetap dilestarikan sebagai salah satu hasil akulturasi dan pertukaran budaya antara umat Hindu dan umat Islam.

Suatu tradisi akan bertahan jika memiliki suatu fungsi dalam kehidupan masyarakat serta adanya upaya-upaya preventif untuk mencegah punahnya atau memudarnya tradisi dari masyarakat. Komitmen serta keyakinan dari masyarakat untuk menjaga serta memelihara tradisi yang ada. Adapun fungsi dari tradisi yaitu fungsi sosial dan religus. Sama halnya dengan dipertahankannya tradisi ngejot di desa Lenek oleh masyarakat karena beberapa faktor diantaranya (1) faktor kepercayaan, lahirnya tradisi ngejot tidak bisa dilepaskan dari karkteristik masyarakat desa 
Lenek yang sangat percaya/yakin terhadap kebesaran tuhan atas segala rizki dan adanya kewajiban untuk bersadakah kepada sesama. Hal ini sangat berpahala lebih-lebih pada saat perayaan hari raya Idul Fitri yang diekpresikan dalam fesvtival ngejot, (2) faktor budaya, budaya yang merupakan suatu keseluruhan kompleks yang meliputi pengetahuan, kepercayaan, seni, kesusilaan, hukum, adat istiadat, serta kesanggupan dan kebiasaan lainnya yang dipelajari oleh manusia yang mencakup semua rancangan hidup yang tercipta secara historis baik eksplisit maupun implisit, rasional dan non rasional yang ada pada suatu waktu sebagai pedoman yang pontensial untuk prilaku manusia, (3) meningkatkan solidaritas sosial, Manusia dikatakan sebagai mahluk sosial karena pada diri manusia ada dorongan dan kebutuhan untuk berinteraksi dengan orang lain, manusia juga tidak bisa hidup sebagai manusia kalau tidak hidup di tengah-tengah manusia lainnya. Tradisi ngejot sebagai salah satu bentuk ekspresi budaya pada masyarakat di desa Lenek menjadi salah satu upaya untuk meningkatkan solidaritas sosial antar anggota masyarakat, (4) faktor pendidikan, Manusia dimanapun dia berada, tidak dapat dipisahkan dari lingkungan masyarakat. Manusia sebagai makhluk dalam evolusi lebih bergantung kepada kebudayaan, dan bukan kepada naluri atau insting. Masyarakat dan kebudayaannya menjadi bergantung kepada keefektifan sosialisasi, yaitu sejauh mana anak mempelajari nilai-nilai, sikap-sikap dan tingkah laku masyarakat dan keluarganya. Oleh karena itu, masayarakat harus membentuk atau menuntut unit yang meneruskan nilai-nilai kepada generasi berikutnya, (5) pemenuhan kebutuhan akan keselamatan, Manusia memiliki pengetahuan dan daya nalar yang terbatas sehingga tidak mampu menembus hal-hal di luar kemampuan manusia. Manusia menyakini adanya hal- hal yang gaib. Dengan keterbatasannya inilah, manusia berusaha mencari perlindungan dan keselamatan diluar dirinya. Kesadaran ini melahirkan usaha- usaha untuk mendekatkan diri pada Tuhan serta upaya menghindari kekuatan yang sifatnya negatif sehingga terciptalah upaya memberikan sesaji atau upacara yang berkaitan dengan keagamaan, dan (6) faktor ekonomi, Tradisi ngejot yang dilaksanakan oleh masyarakat Islam desa Lenek juga terkandung nilai ekonomis. Hal ini tampak pada penggunaan alat dan bahan yang dipakai, seperti: kayu, bambu, bunga, dan berbagai hasil panen yang kesemuanya adalah sudah disediakan oleh alam di desa Lenek. penggunaan berbagi bahan tersebut tentu akan menghemat pengeluaran masyarakat.

Penghulu desa Lenek, Ustad Abdullah menjelaskan, "Ngejot sudah lama digelar masyarakat Lenek sejak zaman pra Islam. Ngejot dari dulu sudah ada di Lenek. Jadi setiap hari raya ada jot, yakni setiap orang mendatangi keluarga, bersilaturahmi, saling mohon maaf. Dikatakan, tradisi yang sudah mengakar pada masyarakat Lenek ini selama ini tidak pernah luntur." Pendapat yang kedua mengatakan bahwa Ngejot merupakan bentuk akulturasi budaya Hinduisme Bali-Islam yang berbenturan dengan kepercayaan lokal pra Islam masyarakat sasak.

Desa Lenek terletak di Kecamatan Aikmel, Kabupaten Lombok Timur yang masyarakatnya berorientasi pada kegiatan pertanian. Pertanian yang diterapkan adalah pertanian dengan irigasi yang cukup. Letaknya yang tidak jauh dari gunung Rinjani menjadikan desa ini menjadikan desa ini memiliki hawa yang sejuk dan curah hujan yang tinggi. Kondisi alam seperti ini menyebabkan Desa Lenek mempunyai tanah yang subur dan dengan sumber daya air yang cukup sehingga kondisi lingkungannya sangat subur.

Kehidupan warga desa Lenek yang sebagian besar hidup dengan mendapatkan penghasilan dari mata pencaharian bertani membuat warga berupaya bersyukur kepada sang pencipta dan kepada keluarga yang telah banyak membantu dalam mengerjakan pertanian dan karenanya masyarakat bisa menanam bahan makanan pokok, seperti jagung, kacang-kacangan, ketela pohon dan lain sebagainya, dengan hasil yang sangat baik, sehingga kebutuhan pokok terpenuhi. 
Berdasarkan kenyataan di atas, dapat dikatakan bahwa hubungan antara alam dan manusia adalah sebuah keharusan yang tidak dapat ditolak, karena hubungan tersebut memiliki nilai- nilai sakral yang sangat tinggi. Dengan demikian, tradisi sebagai wujud ekspresi manusia dalam menyelaraskan hubungan manusia dengan alam dan tuhan salah satunya adalah tradisi ngejot di desa Lenek, Aikmel, Lombok Timur.

Tradisi itu hingga sekarang masih dipertahankan. Masyarakat kaula bala datang ke tokoh masyarakat membawa dulang seraya menyampaikan kata saling mohon maaf dengan iringan harap, keridaan Allah, Tuhan Yang Maha Kuasa.

2. Tata Cara Pelaksanaan Tradisi Ngejot

Tradisi ngejot ini tidak hanya menjadi tradisi masyarakat Lenek, tetapi juga menjadi tradisi masyarakat Sasak, suku mayoritas di Pulau Lombok. Di sejumlah tempat, istilah ngejot ini dikenal dengan istilah Ngater. Namun saat ini, tradisi ngejot atau ngater ini tidak lagi menjadi kebiasaan missal masyarakat. Salah satu desa yang tetap mempertahankan tradisi ini secara massal adalah desa Lenek.

Ngejot dilakukan sekali dalam setahun. Yakni pada hari terakhir bulan puasa Ramadhan, menjelang Hari Raya Idul Fitri. Pada awalnya, ngejot sekadar kegiatan bejango dan betanjak (berbagi). Kemudian berubah dalam wujud silaturahmi yang sakral antara keluarga kepada pemimpinnya. Ngejot termasuk salah satu kebudayaan yang bernilai tinggi. Didalamnya mengandung ungkapan rasa syukur dengan membawa sesaji.

Makna filosofi yang bisa ditarik dalam tradisi ngejot, adalah wujud aktualisasi nilai Islam. Dimana, setiap umat tidak bercerai berai dengan sesama. Tali silaturrahmi itu tidak boleh putus. Termaktub dalam ajaran Islam, barang siapa yang memutuskan silaturrahmi maka mereka tidak akan dapat mencium bau surga. Penafsiran lainnya, ngejot sebagai rangkaian akhir dari perjuangan menahan hawa nafsu selama sebulan penuh berpuasa. Kesannya, belum sempurna jika seseorang melaksanakan lebaran namun belum melakukan prosesi ngejot.

Pada hari terakhir Ramadan, mereka ramai-ramai menyediakan dulang (nampan) berisi makanan untuk sanak keluarga mereka. Tradisi berbagi makanan ini dikenal dengan nama Ngejot. Dulang itu dibawa oleh kaum perempuan. Beriringan berjalan kaki, mereka kumpul di lapangan desa setempat. Dulang itu ditaruh di atas kepala mereka, setelah semua jenis makanan ditata di atas piring. Dulang itu ditutup dengan penutup dulang warna merah yang terbuat darian yaman daun enau atau pohon aren. Setelah kurang lebih seribu warga kumpul dengan dulang mereka, barulah rangkaian acara ngejot dimulai.

Ritual dimulai dengan pengambilan air wudlu yang dilakukan para tokoh masyarat, tokoh adat, pemusungan (kepala desa) dan tokoh agama. Pengambilan air wudlu ini dilakukan sebelum para tokoh tersebut memasuki areal dilangsungkan ritual ngejot. Pengambilan air wudlu dimaksudkan untuk membersihkan badan secara fisik dan batin. Pasalnya, dalam prosesi ritual ada acara doa bersama dipimpin penghulu agama. Setelah wudlu, para tokoh yang nantinya akan menerima dulang memasuki areal ritual. Soal posisi duduk para tokoh itu pun diatur. Yakni, pemusungan diapit mangku adat dan penghulu agama.

Ngejot dimulai dengan prosesi adat dari tiga unsure kepemimpinan masyarakat Sasak yang ada di Lenek, yakni mangku adat, pemusungan (kepaladesa) dan penghulu agama. Mangku adat direpresentasikan oleh tokoh adat/tokoh masyarakat, pemusungan merupakan representasi pemerintah, dan seorang ustadz merupakan representasi penghulu agama. Ketiga perwakilan itu duduk di atas sebuah panggung kecil berbentuk segi empat di tengah lapangan. Sesuai adat istiadat, posisi duduk ketiga pimpinan ini di sebalah utara.Prosesi kemudian berlanjut para acara penyerahan abah-abah atau sesaji yang terdiri dari dulang, penginang dan lekesan, ceceret tanah, tikar serta bantal. Penyerahan dilakukan oleh perwakilan masyarakat. Para pengantar abah-abah tersebut, terlebih dulu berputar mengelingi areal ritual sebanyak 
tujuh kali. Setelah memasuki areal ritual dan duduk di depan pemusungan, ijab kabul atau serah terima abah-abah dilakukan. Berlanjut ke acara pembacaan doa selamat dan prosesi ritual dinyatakan selesai.Abah-abah yang diserahkan perwakilan masyarakat ini kemudian ditukar dengan makanan seperti beras, gula, buhan-buhan dan sembako lainnya.

Setelah prosesi simbolis ini selesai, seluruh masyarakat bejalan beriringan menjunjung dulang sampai keperempatan desa yang yerletak di depan masjid besar Desa lalu berpencar menuju rumah orang tua atau mertua mereka masing-masing untuk menyerahkan dulangnya.

Tradisi ngejot ini, bisa dibedakan tergantung dari tujuan ngejot. Pertama, ngejot seorang anak kepada orang tuanya sebagai wujud permintaan maaf dan merupakan wujud rasa hormat dan bakti kepada kepada orang tua atas asuhan sejak lahir hingga ke jenjang pernikahan. Ada juga ngejot kepada saudara tertua dari adik-adiknya sebagai bentuk rasa hormat. Ada juga ngejot seorang kerabat dan keluarga lainnya untuk tetap menjalin kekeluargaan dan silaturrahmi. Dan terakhir, ngejot warga kepada pemimpinnya, sebagai bentuk saling memaafkan antara masyarakat dengan pemimpinnya dan sebagai ucapan syukur terima kasih kepada pemimpin yang dianggap bisa memberikan tauladan. Jika seorang anak tidak dating Ngejot kepada orang tua, kakak dan kerabatnya, secara tidak langsung orang tua merasa tidak dihargai dan tidak diperhatikan oleh anak atau menantunya. Sedangkan untuk seseorang yang tidak melakukan prosesi Ngejot ini secara tidak langsung mendapatkan sanksi berupa cemoohan dari keluarga.

Ngejot termasuk salah satu kebudayaan yang bernilai tinggi. Di dalamnya mengandung ungkapan rasa syukur dengan membawa sesaji. Makna filosofi yang bisa ditarik dalam tradisi Ngejot, adalah wujud aktualisasi nilai Islam. Di mana, setiap umat tidak bercerai berai dengan sesama. Tali silaturrahmi itu tidak boleh putus. Termaktub dalam ajaran Islam, barang siapa yang memutuskan silaturrahmi maka mereka tidak akan dapat mencium bau surga.

3. Nilai-nilai Pendidikan Islam

Multikultural dalam Tradisi Ngejot

Berdasarkan pemaparan tujuan pendidikan Islam di atas, maka sangat jelas bahwa nilai-nilai pendidikan multikultural yang ada pada tradisi Ngejot pada masyarakat Sasak Lenek memiliki keterkaitan dengan nilai-nilai pendidikan Islam. Pada hakikatnya agama menginginkan manusia memilki perilaku atau akhlak mulia terutama kepada sesame manusia tanpa memandang agama, suku, dan ras seseorang. Selanjutnya, untuk lebih detailnya perlu dikaji lagi tentang nilainilai pendidikan Islam multikultural yang terdapat pada tradisi Ngejot ditinjau dari perspektif pendidikan. Adapun penjelasannya sebagai berikut.

a. Menjaga silaturahim (Berkomunikasi)

Hal pertama yang terdapat dalam Ngejot adalah sarana berkomunikasi antar umat beragama, komunikasi antar personal adalah salah satu cara membangun relasi, jika relasi sudah terjalin, maka hubungan antar umat beragama akan terjalin secara intens. Membangun relasi dalam konteks agama Islam adalah silaturrahim, dengan mempererat tali silaturrahim, hubungan antar umat beragama akan tetap terjaga. Silaturrahim merupakan salah satu agenda utama di momen Idul Fitri atau Lebaran untuk berkunjung ke keluarga, sanak saudara, tetangga, dan masyarakat dalam tradisi Muslim di Indonesia. Bahkan untuk tujuan menyambung tali kasih ini, masyarakat berbondong-bondong pulang kampung atau mudik setiap tahunnya. Selain agenda utama, silaturrahim secara syariat juga merupakan amalan utama karena mampu menyambungkan apa-apa yang tadinya putus dalam relasi hablum minannas. Belum lagi keutamaan dari amalan ini yang di antaranya dapat memperpanjang umur serta melapangkan rezeki.

Terkait substansi silaturrahim ini, Muhammad Quraish Shihab dalam buku karyanya Membumikan Al-Qur'an: Peran dan Fungsi Wahyu dalam Kehidupan Masyarakat (Mizan) mengungkapkan Sabda Nabi 
Muhammad. Rasulullah shallallahu 'alaihi wasallam bersabda: Laysa al-muwashil bil mukafi' wa lakin al-muwwashil 'an tashil man qatha'ak. (Hadits Riwayat Bukhari) Artinya: "Bukanlah bersilaturrahim orang membalas kunjungan atau pemberian, tetapi yang bersilaturrahim adalah yang menyambung apa yang putus." (HR Bukhari) Dari Sabda Nabi Muhammad tersebut, jelas termaktub bahwa silaturrahim menyambung apa yang telah putus dalam hubungan hablum minannas. Manusia tidak terlepas dari dosa maupun kesalahan sehingga menyebabkan putusnya hubungan. Di titik inilah silaturrahim mempunyai peran penting dalam menyambung kembali apa-apa yang telah putus tersebut.

b. Saling Menasehati dan Tolong Menolong

Dalam ajaran Islam, tolong menolong merupakan kewajiban setiap muslim. Sudah semestinya konsep tolong menolong ini dikemas sesuai dengan syariat Islam, dalam artian tolong menolong hanya diperbolehkan dalam kebaikan dan takwa, dan tidak diperbolehkan tolong menolong dalam hal dosa atau permusuhan. Allah Swt telah menyebutkan perintah tolong menolong dalam firmannya:

"Dan tolong menolonglah kamu dalam mengerjakan kebaikan dan taqwa, dan jangan tolong menolong dalam berbuat dosa dan pelanggaran. Dan bertaqwalah kamu kepada Allah. Sesungguhnya Allah amat berat siksanya." (Al Maidah: 2)

Dari redaksi ayat di atas, dapat kita ketahui bahwa Islam sangat menjunjung tinggi tolong menolong. Tolong menolong telah menjadi sebuah keharusan, karena apapun yang kita kerjakan tentu membutuhkan pertolongan dari orang lain. Maka dalam suatu hadis telah disebutkan, bahwa antara mukmin yang satu dengan yang lainnya bagaikan sebuah bangunan yang saling memperkuat antara sebagian dengan yang lainnya. Pun begitu juga dengan ta'awun,tolong menolong adalah suatu sistem yang benar-benar memperindah Islam. Manusia satu dengan yang lainnya pastilah saling membutuhkan. tidak ada seorang manusia pun di muka bumi ini yang tidak membutuhkan pertolongan dari yang lain.

c. Bersadaqah dengan memberikan hidangan

Sedekah adalah salah satu bentuk ibadah dalam Islam. Ibadah ini dilakukan dengan cara menyumbangkan harta benda kepada pihak-pihak yang membutuhkan. Hari ini, dunia mengenalnya dengan istilah filantropi. Filantropi berasal dari kata philan, bahasa Yunani yang berarti cinta, dan anthropos yang berarti manusia.

Filantropi adalah tindakan seseorang yang mencintai sesama manusia serta nilai kemanusiaan, sehingga menyumbangkan waktu, uang dan tenaganya untuk menolong orang lain. Jadi, menyumbangkan harta hanya sebagian dari cara mencintai sesama manusia.

Filantropi Islam adalah kombinasi antara kepedulian terhadap sesama dan pengabdian kepada Tuhan. Pengabdian kepada Tuhan dilaksanakan dengan cara mempedulikan sesama. Kepedulian menjadi satu bentuk pengabdian, bukan kepada sesama manusia tetapi kepada Tuhan. Kombinasi ini menempatkan filantropi Islam, sebagai kegiatan yang tak terpisahkan dari praktik beragama.

Islam memperkenalkan dua macam filantropi berbasis bantuan kemanusiaan. Pertama, filantropi yang bersifat wajib. Hal ini seperti tercermin dalam ibadah zakat dengan berbagai variannya dan nafkah. Kedua, filantropi yang bersifat anjuran. Seperti sedekah, infak, wakaf dan hibah.

Dalam dua jenis filantropi di atas, Islam sangat menekankan agar pelaksanaannya didasarkan kepada ketulusan. Ketulusan ditunjukkan, di antaranya, dengan memberikan pemberian yang terbaik. Hal ini sebagaimana ditunjukkan oleh QS. Albaqarah: 267.

Allah Swt. berfirman, Hai orang-orang yang beriman, nafkahkanlah (di jalan Allah) sebagian dari hasil usahamu yang baik-baik dan sebagian dari apa yang Kami keluarkan dari bumi untuk kamu. Dan janganlah kamu memilih 
yang buruk-buruk lalu kamu menafkahkan daripadanya. Padahal kamu sendiri tidak mau mengambilnya melainkan dengan memincingkan mata terhadapnya. Dan ketahuilah, bahwa Allah Maha Kaya lagi Maha Terpuji. (QS. Albaqarah: 267)

Syekh Wahbah Al-Zuhaili menyatakan bahwa tema ayat ini adalah kewajiban memilih harta yang baik ketika hendak berinfak di jalan Allah SWT, baik infak tersebut berupa zakat wajib maupun sedekah sunnah. Karena tujuannya adalah mendekatkan diri kepada Allah SWT dan menabung pahala dengan beramal baik. Tujuan ini tidak bisa diraih kecuali jika harta yang diinfakkan adalah harta yang baik pula." (Tafsir Al-Munir, jilid 2, hlm. 87).

d. Tidak Saling Menyakiti atau Saling Menyayangi

Islam mengajarkan agar sesama manusia saling menjalin kasih sayang dan atau mencintai. Dalam sebuah hadits nabi dikatakan bahwa, tidak sempurna iman seseorang hingga yang bersangkutan sanggup mencintai orang lain sebagaimana ia mencintai dirinya sendiri. Seseorang tidak akan mungkin mau dirinya susah, menderita, menanggung kerugian, dan apalagi celaka. Begitu pula, sebagai bentuk kecintaan terhadap sesama, semestinya orang lain pun tidak boleh menanggung perasaan yang ia sendiri membencinya itu.

Kecintaan terhadap dirinya sendiri, hartanya, jabatannya, dan kedudukannya, ternyata belum berhasil diimbangi dengan kecintaannya terhadap sesama. Bahkan sebaliknya, sedemikian tinggi kecintaan terhadap hal-hal yang terkait dengan dirinya sendiri itu memunculkan kebenciannya terhadap orang lain. Orang lain dibenci oleh karena dianggap mengganggu, menjadi pesaing, dan keberadaannya tidak menguntungkan dirinya. Padahal, Islam mengajarkan sebaliknya. Antar sesama harus saling mengenal, memahami, menghargai, menjalin kasih sayang, dan saling tolong menolong dalam kebaikan.

e. Duduk Bersama (Bermusyawarah)
Sedangkan hal ketiga yang terdapat dalam ngejot adalah duduk bersama tanpa memandang status sosial dan agama, dalam artian, dalam kunjungan ketika melakukan ngejot kepada non muslim, kita bisa berkumpul duduk bersama, saling menhargai tanpa adanya sekat-sekat status sosial ataupun agama, hal ini terjadi atas dasar dorongan kemanusiaan untuk menjaga toleransi. Dengan catatan, kesamaan (musawa) dan toleransi yang dilakukan tidak sampai melewati batasan Aqidah, seperti peringatan Allah dalam Surah al-Kafirun: berbeda agama ini menyebabkan kerusuhan dan tertutupnya akses warga muslim selama 3 hari. Faktanya, konflik yang pernah terjadi di desa ini tidak menghalangi para warga desa untuk tetap melakukan tradisi in sampai sekarang. Jika metode dakwah bil hal yang dibungkus dalam tradisi ini tetap dilakukan secara konsisten, maka bukanlah hal yang mustahil bahwa kerukunan dan keharmonisan antar umat beragamana adalah sebuah keniscayaan.

Tentang prinsip musyawarah, Al-Qur'an mengajarkan, "Maka disebabkan rahmat dari Allahlah, engkau bersikap lemah lembut terhadap mereka. Seandainya engkau bersikap kasar dan berhati keras, niscaya mereka akan menjauhkan diri dari sekelilingmu. Karena itu, maafkanlah mereka, mohonkanlah ampun bagi mereka, dan bermusyawarahlah dengan mereka dalam urusan (tertentu). Kemudian apabila engkau telah membulatkan tekad, bertawakallah kepada Allah. Sesungguhnya Allah menyukai orang-orang yang bertawakal kepada-Nya." (QS Ali 'Imran [3]: 156) Menurut Quraish Shihab (200), ayat ini dari segi redaksional ditujukan kepada Nabi Muhammad agar memusyawarahkan persoalan-persoalan tertentu dengan sahabat atau anggota masyarakatnya. Tetapi ayat ini juga merupakan petunjuk kepada setiap Muslim, khususnya kepada setiap pemimpin, agar bermusyawarah dengan anggota-anggotanya. Dari ayat Surat Ali 'Imran di atas bisa digarisbawahi tentang lemah lembut, bersikap kasar dan berhati keras serta saling memaafkan. Hal itu merupakan poin-poin penting dalam bermusyawarah, termasuk 
dalam memilih pemimpin dalam proses pemilihan umum seperti di Indonesia. Hendaknya sikap lemah lembut, tidak kasar dan tidak keras hati serta saling memaafkan menjadi fondasi kokoh dalam mempererat tali persaudaraan warga sebangsa dan setanah air.

\section{f. Melawan Hawa Nafsu}

Hawa nafsu adalah sebuah perasaan atau kekuatan emosional yang besar dalam diri seorang manusia; berkaitan secara langsung dengan pemikiran atau fantasi seseorang. Hawa nafsu merupakan kekuatan psikologis yang kuat yang menyebabkan suatu hasrat atau keinginan intens terhadap suatu objek atau situasi demi pemenuhan emosi tersebut. Dapat berupa hawa nafsu untuk pengetahuan, kekuasaan, dan lainnya; namun pada umumnya dihubungkan dengan hawa nafsu seksual. Sebenarnya setiap orang diciptakan dengan potensi diri yang luar biasa, tetapi hawa nafsu dapat menghambat potensi itu muncul kepermukaan. Potensi yang dimaksud di sini adalah potensi untuk menciptakan keadilan, ketenteraman, keamanan, kesejahteraan, persatuan dan halhal baik lainnya. Namun karena hambatan nafsu yang ada pada diri seseorang potensipotensi tadi tidak dapat muncul kepermukan (dalam realita kehidupan). Maka dari itu mensucikan diri atau mengendalikan hawa nafsu adalah keharusan bagi siapa saja yang menghendaki keseimbangan, kebahagian dalam hidupnya karena hanya dengan berjalan di jalur-jalur yang benar sajalah menusia dapat mencapai hal tersebut.

g. Menjaga Perdamaian dan Keamanan

Manusia yang telah "dianugrahi" aqal dan nafsu dipercaya oleh Tuhan untuk menjadi khalifah-Nya dengan misi menjaga bumi dari kerusakan. Tentu untuk menjadi balance antara ke dua kekuatan yang dimiliki manusia tersebut Agama adalah jawabannya. Oleh karennya Allah mengutus rasul-rasul-Nya guna menyebarkan ajaranajaran yang dapat menjadi pelita manusia dalam mengarungi bahtera kehidupan ini. Islam merupakan penyempurna dari ajaranajaran sebelumnya. Dan ia adalah agama samawi terakhir yang dibawa oleh rasul terakhir dan untuk umat terakhir yang hidup di zaman akhir. Dengan berpedoman pada Al- Qur'an dan Assunnah maka Islam mempu menjawab tantangan zaman semenjak kemunculannya, zaman ini hingga yang akan datang.

h. Patuh dan Taat kepada Pemimpin

Ketaatan kepada pemimpin adalah suatu kewajiban sebagaimana disebutkan dalam AlQur'an dan Hadits sangat banyak sekali. Dalil di dalam Al-Qur'an di antaranya adalah


"Hai orang-orang yang beriman, taatilah Allah dan taatilah Rasul (Nya), dan ulil amri di antara kamu." (QS. An Nisa' [4]: 59) Dalam ayat ini Allah menjadikan ketaatan kepada pemimpin pada urutan ketiga setelah ketaatan pada Allah dan Rasul-Nya. Namun, untuk pemimpin di sini tidaklah datang dengan lafazh perintah "taatilah" karena ketaatan kepada pemimpin merupakan ikutan (tâbi') dari ketaatan kepada Allah dan Rasul-Nya shallallahu 'alaihi wa sallam. Oleh karena itu, apabila seorang pemimpin memerintahkan untuk berbuat maksiat kepada Allah, maka tidak ada lagi kewajiban mendengar dan taat kepada mereka.

Kita harus memperhatikan kewajiban mendengar dan taat kepada penguasa. Karena, bila kita tidak menaati mereka, maka akan terjadi kekacauan, pertumpahan darah dan terjadi korban pada kaum muslimin. Ingatlah bahwa darah kaum muslimin itu lebih mulia daripada hancurnya dunia ini.

\section{i. Memupuk toleransi}

Toleransi dalam masyarakat majemuk dirasa penting, untuk terus menjaga silahturahmi warga dari berbagai suku, bahasa, budaya dan agama yang ada di NKRI. Toleransi dalam agama, sifat atau sikap menghargai orang lain, yang berbeda dengan pendapatnya. Sebaik-baiknya manusia harus berguna bagi orang lain. Kebebasan beragama merupakan bagian dari penghormatan terhadap hak-hak manusia yang sangat mendasar. Dalam konteks sosial dan agama toleransi diwarnai sikap dan perbuatan yang melarang adanya diskriminasi kelompok-kelompok yang berbeda atau tidak diterima oleh mayoritas dalam masyarakat. 
Sikap toleransi dan menghargai tidak hanya berlaku terhadap orang lain, terhadap yang berbeda agama dan keyakinan juga tetap mengenal toleransi.

Dalam menyikapi keberagaman wajib dilandasi nilai-nilai Pancasila, UUD 45, NKRI dan Bhineka Tunggal Ika. Negara Indonesia berdasarkan Ketuhanan Yang Maha Esa, dengan demikian konteks kehidupan berbangsa dan bernegara haruslah berlandaskan nilai-nilai ketuhanan. Nilai-nilai agama dan budaya tidak dijadikan sumber etika dalam berbangsa dan bernegara. Semua agama mengajarkan tentang kebaikan. Adanya nilai-nilai budaya sebagai sumber etika dan moral.

Terjadinya konfik sosial budaya terjadi karena salah dalam mengartikan toleransi, selain itu kesenjangan ekonomi, praktek birokrasi yang diwarnai KKN, praktek demokrasi yang mencampur adukan kepentingan pribadi dan kelompoknya. Toleransi dari prespektif tradisi Ngejot menjadikan nilai-nilai agama dan budaya sebagai sumber etika kehidupan dalam rangka memperkuat akhlak dan moral. Sejarah perjuangan bangsa Indonesia telah mencatat peran penting, sebagai garda terdepan bangsa ini.

\section{KESIMPULAN}

Pendidikan multikultural di Indonesia lebih tepat dipandang sebagai pendekatan, yaitu pendekatan pendidikan yang mengupayakan agar nilai-nilai budaya kedaerahan (suku bangsa) dan agama di Indonesia dapat dipahami, dihargai, dan dimanfaatkan untuk kepentingan pendidikan kebangsaan-kewarganegaraan berlandaskan semboyan "bhinneka tunggal ika" dan falsafah Pancasila, dengan mengedepankan toleransi dan kerukunan antar budaya dan pemeluk agama.

Bahwa kehidupan masyarakat multikultural yang dikemas dengan tradisi Ngejot masyarakat Sasak Lenek memiliki karakteristik dan keunikan tersendiri dibanding dengan daerah-daerah lain di Indonesia yang selalu diselimuti konflik dan kekerasan atas nama agama. Masyarakat multikultural di desa
Lenek Aikmel kabupaten Lombok Timur menunjukkan adanya nilai-nilai sakral yang diwarisi secara turun temurun oleh leluhur dalam membangun masyarakat yang pluralis.

Agama Islam Multikultural adalah menciptakan masyarakat madani yang menjunjung tinggi konsep masyarakat pluralis, yaitu sebuah konsep yang setiap individu dan kelompok memiliki hak dan kewajiban sama, meskipun mereka berada di bawah latar belakang yang berbeda. Beberapa keterangan mengenai tujuan pendidikan Islam di atas sesuai dengan tujuan pendidikan multicultural, yaitu untuk menciptakan kehidupan yang harmonis dalam masyarakat yang serba majemuk.

Nilai-nilai karakter yang terkandung dalam Tradisi Ngejot masyarakat Sasak Lenek, antara lain: (1) nilai silaturrahmi (berkomunikasi), (2) saling menasehati dan tolong menolong, (3) bersedeqah, (4) saling menyanyangi, tidak boleh menyakiti satu sama lain, (5) ajaran bermusyawarah (duduk bersama) menyelesaikan persoalan, (6) melawan hawa nafsu, (7) menjaga perdamaian dan keamanan, (8) patuh dan taat kepada pemimpin, dan (9) memupuk toleransi.

\section{DAFTARA PUSTAKA}

Abdullah, M.Amin. Pendidikan Agama Era Multikultural-Multireligius. Jakarta: PSAP, 2005.

Abdillah, Masykuri Demokrasi di Persimpangan Makna: Respons Intelektual Muslim Indonesia terhadap Konsep Demokrasi 1966-1993, tanpa tahun.

Achmadi, Abu. Islam Sebagai Paradigma Ilmu Pendidikan. Yogyakarta: Aditya Media, 1992.

Afandi, Ahmad. Kepercayaan Anisme-Dinamisme Serta Adaptasi Kebudayaan Hindu-Budha Dengan Kebudayaan Asli di Pulau Lombok-NTB, Jurnal Historis, Vol. 1, No. 1, Desember 2016.

Aly, Abdullah. Pendidikan Islam Multikultural di Pesantren, Telaah terhadap Kurikulum Pondok Pesantren Modern Islam Assalaam 
Surakarta. Yogyakarta: Pustaka Pelajar, 2011.

Al-Abrasyi, Athiyyah. At-Tarbiyyah alIslamiyyah wa Falsafatuha. Beirut: Dar al-Fikr, 1969.

Al-Abrasyi, Moh. Athiyyah. Psikologi Pendidikan Suatu Pendekatan Baru. Bandung: PT. Rosdakarya, 2005.

Aly, Hery Noer dan Munzier. Watak Pendidikan Islam. Jakarta: Priska Agung Insani, 2008.

Al Quran Al Karim Cetakan Departemen Agama RI.

Assegaf, Abd. Rahman. Politik Pendidikan Nasional. Yogyakarta: Kurnia Kalam, 2005.

Baharun, Hasan. Tradisi Ngejot: Sebuah Ekspresi Keharmonisan dan Kerukunan Antar Umat Beragama dengan Dakwah Bil Hal. Fenomena, Jurnal Penelitian, volume 10 no. 1 tahun 2018.

Dawam, Ainurrofiq. "EMOH" Sekolah: Menolak "Komersialisasi Pendidikan" dan "Kanibalisme Intelektual" Menuju Pendidikan Multikultural. Yogyakarta: Inspeal Ahimsakarya Press, 2003.

Driyarkara. Tentang Pendidikan. Jakarta: Kanisius, 1980.

Effendi, Johan. Kemusliman dan Kemajemukan Agama. Yogyakarta: Pustaka Pelajar, 2004.

Faisal, Yusuf Amir. Reorientasi Pendidikan Islam. Jakarta: Gema Insani Press, 1995.

Fitri, Agus Zaenul. Manajemen Kurikulum Pendidikan Islam; dari NormatifFilosofis ke Praktis. Bandung: Alfabeta, 2013.

Hamzah, Umar Yusuf. Ma'alim al-Tarbiyah fi Al-Qur'an wa al-Sunnah. Dar Usamah, Yordania, 1996.

https://islam.nu.or.id/post/read/79244/maknasilaturrahim-dalam-sabda-nabimuhammad, diakses tanggal 06 November 2019.

https://id.wikipedia.org/wiki/Hawa_nafsu, diakses 06 N0vember 2019.

I Ketut Wiana, Naskah Untuk Mimbar Agama Hindu di Bali Post., http://bukuspiritual.blogspot.com/20 16/11/makna-ngejot-dalam-tradisihindu-di-bali.html.

Ibrahim, Rustam. Pendidikan Multikultural: Pengertian, Prinsip, dan Relevansinya dengan Tujuan Pendidikan Islam, Jurnal Addin, Vol. 7, No. 1, Februari 2013.

Idris, Zahara. Dasar-dasar Kependidikan. Padang: Angkasa Raya, 1987.

Khadiri, Muhammad Abdul Basir Muqaddimah fi An Nudzum Al Islamiyah, 2003.

Khalaf, Abd al-Wahhab. Ilm Ushul al-Fiqh. Kuwait: Dar al-Qalam, 1978.

Mahfud, Choirul. Pendidikan Multikultural. Yogyakarta: Pustaka Pelajar, 2006.

Maksum. Madrasah, Sejarah dan Perkembangannya. Jakarta: Logos Wacana Ilmu, 1999.

Maksum, Ali. Pluralisme dan Multikulturalisme Paradigma Baru Pendidikan Agama Islam di Indonesia. Malang: Aditya Media Publishing, 2011.

Marimba, Ahmad D. Pengantar Filsafat Pendidikan Islam. Bandung: Al Ma'aif, 1980.

Maslikhah. Quo Vadis Pendidikan Multikultural: Reconstruksi Sistem Pendidikan berbasis Kebangsaan. Surabaya: JP Books, 2007.

Mukhtar, Maksum. Madrasah, Sejarah \& Perkembangannya. Jakarta: Logos, 1999.

Naim, Ngainun dan Achmad Sauqi. Pendidikan Multikultural Konsep dan Aplikasi. Yogyakarta: Ar-Ruzz Media, 2008.

Nasution, Harun. Islam ditinjau dan Berbagai Aspeknya, Jilid I. Jakarta: UI Press, 1979.

Nata, Abudin. Manajemen Pendidikan; Mengatasi Kelemahan Pendidikan di Indonesia. Jakarta: Kencana Media Group, 2010.

Nata, Abuddin. Tokoh-Tokoh Pembaruan Pendidikan Islam di Indonesia. 
Jakarta: Raja Grafindo Persada , 2005.

Oase. (2014, Desember 11). PDBI Ritual. Retrieved from PDBI: https://budayaindonesia.org/Ngejot/.,http://www.in fobudaya.net/2019/01/bertoleransidengan-tradisingejot/.,https://www.nu.or.id/post/rea d/60994/bali-miliki-tradisiquotngejotquot-dalam berlebaran, diakses tanggal 06 November 2019.

Partanto, Pius A M. dan Dahlan Al Barry. Kamus Ilmiah Populer. Surabaya: Arkola, 1994.

Poeradisastra, S.I. Sumbangan Islam terhadap Peradaban Modern. Jakarta: P3M 1984.

Prof.Imam Supraogo, Mencintai Sesama, https://uinmalang.ac.id/r/140101/mencintaisesama.html, diakses 06 November 2019.

Raka, I Gd. Et al. Pendidikan Karakter di Sekolah dari Gagasan ke Tindakan. Jakarta: Kompas Gramedia, 2011.

Ramadhani, Y. Tirto Sosial Budaya. Retrieved from Tirto: https://tirto.id/menjaga-kerukunandi-bali-dengan-tradisi-ngejot-crmr, (2017, Juni 28).

Rumagit, Stev Koresy. Kekerasan dan Diskriminasi Antar Umat Beragama di Indonesia, dalam Jurnal Lex Administratum, Vol. I, No.2, Januari. Manado: Universitas SAM Ratulangi, 2013.

Setiawan, Zudi. Nasionalisme NU. Semarang: Aneka Ilmu, 2003.

Suparlan, Parsudi. Menuju Masyarakat Indonesia yang Multikultural, Makalah disampaikan pada Simposium Internasional Bali ke-3, Jurnal Antropologi Indonesia, Denpasar Bali, 16-21 Juli 2002.

Tafsir, Ahmad. Epistimologi untuk Ilmu Pendidikan Islam. Bandung: UIN Sunan Jati, 1995.

Tilaar, H.A.R. Multikulturalisme: Tantangantantangan Global Masa Depan dalam
Transformasi Pendidikan Nasional. Jakarta: Grasindo, 2004.

Tobroni. Pendidikan kewarganegaraan Demokrasi, HAM, Civil Society dan Multikultural. Yogyakarta: PusaPom, 2007.

Usa, Muslih dan Aden Wijaya. Pendidikan Islam dalam Peradaban Industrial. Yogyakarta: Aditia Media, 1987.

Wahid, Solahuddin. Tranformasi Pesantren Tebuireng Menjaga Tradisi di Tengah Tantangan. Malamg: UIN Maliki Press, 2011.

Yaqin, M. Ainul. Pendidikan Multikultural: Cross-Cultural Understanding untuk Demokrasi dan Keadilan. Yogyakarta: Pilar Media, 2005.

Zuhairini, dkk. Metodik Khusus Pendidikan Agama. Bandung: Usaha Offset,1983.

Zuhairini, dkk. Sejarah Pendidikan Islam. Jakarta: Bumi Aksara, 1992. 